\title{
The emergence of using pegs in securing tenons in mortises by ancient Egyptian shipbuilders
}

\section{Marwan Mady}

Central Department for Underwater Antiquities-Ministry of Antiquities, 19 Abd El-Moaty El-Ghazaly Street Istanly-Alexandria - Egypt, E-mail: marwan_fathy89@yahoo.com.

Alexandria Centre for Maritime Archaeology and Underwater Culture Heritage, Egypt.

\begin{abstract}
Throughout the Pharaonic periods, Egyptian shipbuilding witnessed various fastening methods in ships during their evolution. It was believed that Egyptian shipbuilders avoided using pegged mortise and tenon joints as a construction method in the Late Period, because of the influence and interaction with the Mediterranean. This paper aims to present a new analytical theory depending on the evidence in Wadi Gawasis, which presents the earlier use of pegs in Egypt during the Middle Kingdom. Wadi Gawasis becomes the first physical evidence for the use of this method, in the absence of earlier examples in the Mediterranean.
\end{abstract}

\section{Key words}

Maritime archaeology, shipbuilding, Egyptian fastening methods, Middle Kingdom, pegs, pegged mortise and tenon.

\section{Introduction}

Egyptian and Mediterranean shipbuilding are characterised by different traditions of fastening hull planking. Egyptian shipbuilders avoided securing their ships by using pegged mortise and tenon joints, allowing them to disassemble, reassemble, transport, recycle, and transfer vessels across the desert from the Nile River to the Red 
Sea (Ward, 2009:15). The first physical evidence which supports that point of view is Mataria boat (described below) (Wachsmann,1998:222), which demonstrates the influence and interaction with Mediterranean peoples through the Early Late Period, ca. 500 BC (Ward,2000:133).

On the other hand, in the Mediterranean, shipbuilders were using pegged tenons to fasten planks together (Wachsmann, 1998:206; Ward, 2000:134; Belov, 2019:61). In this author's opinion, this may have been because their owners did not need to transport ships from one body of water to another, and to prevent planks from longitudinal slippage caused by the forces of the sea. The oldest example, the Uluburun shipwreck was discovered in 1983, $50 \mathrm{~m}$ from the coast near the town of Kaş, (Fig.1) on the south coast of Turkey (Wachsmann, 1998:206; Abd el-Maguid, 2009:81). This ship dates back to 1315 BC according to dendrochronological analysis (Wachsmann, 1998:206). Its strakes are fastened with pegged mortise and tenon joints, with pegs about $2.2 \mathrm{~cm}$ in diameter on the hull's inner surface locking each joint together (Fig.2) (Wachsmann, 1998:216; Pulak, 2003:29).

This paper will discuss the shreds of evidence and reasons behind the lack of use of pegs to secure tenons in mortises by ancient Egyptian shipbuilders. Additionally, it may be that the ancient Egyptians adopted this practice from general woodworking methods practiced locally, and not from Mediterranean shipbuilding practice.

\section{Hull planks T64 and T34}

The first direct evidence is the two massive hull planks, T64 and T34, which were found in Mersa Wadi Gawasis harbour. The site consists of seven caves (Fig.3). The harbour and its caves were built for operations of state expeditions staged from Koptos to Punt for c.500 years (Ward et al., 2010:387). The site was dated to the Middle Kingdom, according to a wooden box that was found in SU25 (strategic unit 25) in WG32 (Wadi Gawasis 32) in front of cave 6, which has an inscription referring to Amenemhet IV, who ruled Egypt between 1786 to 1778 BC (Fig.4) (Mahfouz and Pirelli, 2007:47; Mahfouz, 2007:238; Ward et al., 2010: 389).

The T64 hull plank was located in front of cave 3 and its dimensions are $106 \mathrm{~cm}$ in length, $50.5 \mathrm{~cm}$ in width, and 22.5 in cm thickness (Fig.5). The good condition of this segment provides us with considerable detail about its fastening methods such as dovetail fastenings, ligatures of copper strips, angles of dovetail mortises to adjacent plank positions, and pairs of double mortise-and-tenon joints in inboard and outboard edges. Two pairs of mortise-and-tenon joints are present, with the following characteristics: pegs are $2 \mathrm{~cm}$ in diameter; pegs were driven from the inner face to $9.5 \mathrm{~cm}$ from the planks' outboard surface; pegs pass through both tenons in each pair of outboard joints. When archaeologists extracted the upper tenons, they found that each peg passed through the upper mortise and tenon and stopped in the middle of the lower tenon. This practice avoids penetrating the hull and indicates a high level of shipbuilding skill (Zazzaro and Calcagno, 2007:31; Ward et al., 2010:387-388; Zazzaro and Calcagno, 2012:67).

The other hull segment, T34 is knife-shaped (Fig.6); its dimensions are $293 \mathrm{~cm}$ in length, $46 \mathrm{~cm}$ in width and $15 \mathrm{~cm}$ in thickness (Ward, 2007: 138; Ward and Zazzaro, 2010:32). It was located in WG32 at cave 6 in the same level with the inscribed wooden box of Amenemhet IV, but it was found in SU9 in very good condition. 
Note that SU9 and SU25 are found in WG32 at the same level (Zazzaro 2019, personal communication, 21-22 May; Ward,2007: 138, 147, 303; Zazzaro, 2007: 187; Zazzaro and Calcagno, 2007:31). Furthermore, T34 provides us with more details of its fastening, include deep mortise and tenon joints, copper strips in L-shaped channels and 25 double mortises and tenons; three of which were secured by pegs (Ward and Zazzaro, 2010: 32, 36; Zazzaro and Calcagno, 2012:70). T64 is a segment of a strake fastened to the keel. Ward, Zazzaro and Abd el-Maguid suggested that T64 was cut from the tip of a knife-shaped plank (Ward et al., 2010:389), so both two segments provide five pegs securing five double mortises and tenons.

\section{A ship construction scene}

The author investigated the indirect evidence for the chronological use of pegs in ancient Egypt. A painting of a ship construction scene in the 19th Dynasty tomb of Qaha at Deir el Medinah (Ramsis II) shows 13 pegs in different places (Fig.7). Amidships are two men, using a bow drill. According to Wachsmann, these men are drilling the holes and driving the pegs to secure tenons in mortises from inside the hull (1998:236). Ward, however, thought that those pegs might be for fastening frames to the hull, based on the spacing and sizes of the pegs' heads (2000:115).

\section{The Mataria boat}

Back to the direct evidence, the Mataria boat was dated to the Late Period, ca. 500 BC. The boat was discovered in 1987 during construction work near Heliopolis in El Mataria (Fig.8). The boat was located $10 \mathrm{~m}$ deep in the sand, suggesting that it was abandoned near one of the old Nile canals. However, about one-third of it was destroyed by heavy machinery (Abd el-Maguid, 2009:105, 108). Based on reports from construction workers, the hull's dimensions are estimated at $11 \mathrm{~m}$ long, $4 \mathrm{~m}$ wide and $1.2 \mathrm{~m}$ deep. The boat has 15 planks on either side of the central strake (Wachsmann, 1998: 222; Abd el-Maguid, 2009:106). All planks in the hull were described as being about $20 \mathrm{~cm}$ in width and about $8 \mathrm{~cm}$ in thickness. This ship used pegged mortise and tenon joints (Fig.9). The pegged tenons' dimensions are $17 \mathrm{~cm}$ (length) x $10 \mathrm{~cm}$ (width) x $2 \mathrm{~cm}$ (thickness). Pegheads are $2 \mathrm{~cm}$ in diameter. This large tenon continues an older Egyptian tradition (Belov,2019:5), similar to the large tenons from the Middle Kingdom as in the T64 segment which had deep mortises and tenons also secured by pegs $2 \mathrm{~cm}$ in diameter (Ward et al., 2010: 388).

The next figure (Fig.10) illustrates a peg and two tenon fragments. The fragment shown on the left is $15.6 \mathrm{~cm}$ (length) $\times 8.5 \mathrm{~cm}$ (width) $\times 2 \mathrm{~cm}$ (thickness). The distorted fragment in the middle, perhaps half of the original tenon, contains a peg hole $1.5 \mathrm{~cm}$ in diameter. There are other tenon fragments that have been identified by Ward with and without pegs (Wachsmann, 1998: 222; Ward, 2000: 131, 133, 134).

\section{Heracleion 17 ship}

The final evidence in this paper is Heracleion ship 17 (see Belov, 2019: figure on the front cover, showing photomosaic of Heracleion 17 shipwreck), which was discovered in 2003. Institut Européen D'Archéologie Sous-Marine (IEASM) recovered it in the port area of the submerged city of Thonis-Heracleion at a depth of 7 - 
$8 \mathrm{~m}$. According to radiocarbon analysis, the ship is dated between the middle of the eighth and the middle of the fourth century BC (Belov, 2014a:314-315).

The ship's hull is assembled with rectangular channels in each plank and tenon ribs (see Belov, 2014a: 324, fig.18), The tenon rib is the long wooden piece that extends into a group of strakes and attaches them together (see Belov, 2014a:320, fig.10, and in Belov, 2014b:169, fig.111), In this case, 24 strakes beside the proto keel were attached together by around 57 tenon ribs through the plank's channels. Tenon ribs were divided into four sets; the first set extended from the proto keel to S4 (strake 4); the second from S4/S5 to S10/S11; the third from S10/S11 to S15/ S16; and the fourth set from S16 to S24. The interior hull pegs are distributed in specific strakes according to the extremities of the tenon ribs and not pegged at all strakes which confined between both ends of tenon ribs (Belov, 2019:61). Strake 4 contains more than one-third of all the starboard pegs recorded, strakes 5,10,11, 15 and 16 contain each between $8.3 \%$ and 12.4\% of all the pegs (see Belov, 2019: 58, fig.5.28) (Belov, 2014a:318, 322, 325-327). In certain parts of the ship, there was no need to dismantle pegs. However, it seems that the shipbuilder wanted either to secure the ends of the tenon ribs or to facilitate disassembly of the ship and reflect the limited use of pegs in some points.

\section{Conclusion}

Egyptians knew about the importance of using pegs to secure wood in place from ancient. They demonstrated their capabilities in employing it in other woodwork such as furniture and coffins. Hence, we might be able to prove that Egyptian shipbuilders used pegs to secure tenons in mortises for protection of the weakest and most highly stressed areas in their ships, and to secure planks from transverse and longitudinal slippage and shifting caused by the forces of the sea during voyages.

The pegs found in some wooden segments from the ship's planks in Wadi Gawasis especially T64 and T34, have been interpreted as probable repairs, or those segments were in storage or being reused. Even if they are considered to be repairs, the author believes they represent the beginning of the use of pegs in ships' hull construction. Nevertheless, the author suggests that these do not represent repairs, but it was a manner applied in ship construction during ancient periods, which reflects the desire of the shipbuilders to secure tenons in mortises by pegs in the weakest points from the shipbuilder's perspective. On the contrary, it may have been to facilitate the disassembly of ships, that they carefully used pegs only in limited cases. Moreover, the tenons in the T64 segment and the Mataria boat are similar in size, and both are accompanied by pegs $2 \mathrm{~cm}$ in diameter, as a consequence of using pegs with large tenons are an original tradition.

In the Wadi Gawasis discovery, there was no complete ship. However, there are two planks, T34 and T64, which could be parts of the same strake. Twenty-nine pairs of double mortises and tenons were investigated, five of them having pegs. In addition to the above evidence, the wall painting on the Qaha tomb indicates the use of pegs at specific points, as interpreted by scholars who have investigated this painting. From the author's perspective, the wall painting reflects and illustrates a true scene for the use of pegs in the shipbuilding industry. Despite that, there is a gap of several hundred years between the discovered ship planks in Wadi Gawasis and the painting, but it may be an indicator of the continuity of using this manner. As Wadi Gawasis provides 
evidence for the use of dovetail mortises and tenons as an ancient method of fastening in ship construction (Creasman,2005:122), this might also be the first evidence for the use of pegs in securing tenons in mortises. Moreover, in the Mataria boat, not all mortises and tenons were pegged, according to Ward (2000:133), Washcmann (1998:222), and Belov (2014a:325). The Heracleion 17 ship, also demonstrates the shipbuilder's use of pegs only to secure the ends of tenon ribs.

According to Washcmann (1998:206) and Pulak (2003:28), the oldest known example for the use of use pegs until now is the Uluburun shipwreck dated to 1315 BC by dendrochronological analyses. The Wadi Gawasis hull segments date back to the Middle Kingdom specifically in the period of Amenemhet IV, who ruled Egypt from 1786 to $1778 \mathrm{BC}$. Thus, Wadi Gawasis is the first evidence of pegged mortises and tenons in ships' hull construction and the oldest to date in the world.

\section{Acknowledgements}

I would like to thank Honor Frost Foundation especially Professor Lucy Blue, for giving me this chance and for her support. Many thanks for Drs. Alexander Belov, Cemal Pulak, Cheryl Ward, Chiara Zazzaro, Kathryn Bard and Mohamed Abd el-Maguid for their help. Furthermore I would like to thank the University of Southampton, the University of Oxford, the MAGS community and HFF for publishing my paper.

\section{References}

Abd el-Maguid, M., 2009, Recherches sur la construction navale antique en Méditerranée orientale de l'Egypte pharaonique à la fin de l'Antiquité: étude archéologique (Published doctoral dissertation, AixMarseille 1), Marseille.

Bard, K. A. and Fattovich, R., 2007, Harbour of the pharaohs to the Land of Punt. Archaeological investigations at Mersa/Wadi Gawasis, Egypt, 2001-2005, 364. Naples.

Belov, A., 2014a, A New Type of Construction Evidenced by Ship 17 of Thonis-Heracleion. International Journal of Nautical Archaeology, 43(2), 314-329.

Belov, A., 2014b, Etudes de l'architecture navale égyptienne de la Basse Epoque: nouvelle évidence archéologique et essai de restitution en $3 D$ (Published doctoral dissertation, Bordeaux 3), Bordeaux. Belov, A., 2019, Ship 17: A Baris from Thonis-Heracleion, Oxford Centre for Maritime Archaeology Monograph 10, Oxford.

Calcagno, C. and Zazzaro, C., 2007, Ship Components, In. K.A. Bard, and R. Fattovich, (eds.) Mersa/Wadi Gawasis, 2006-2007 Report, 30-33, Available at:

https://www.academia.edu/518412/MERSA_WADI_GAWASIS_2006-2007 [Accessed 12 Jul. 2019]. Creasman, P.P., 2005, The Cairo Dashur Boats, (unpublished master dissertation, Texas A\&M University), United States.

Mahfouz, E. and Pirelli, R., 2007, Wooden Box, In. K. Bard and R. Fattovich (eds.) Mersa/Wadi Gawasis, 2006-2007 Report, 47-49, Available at:

https://www.academia.edu/518412/MERSA_WADI_GAWASIS_2006-2007, [Accessed 12 Jul. 2019]. 
Mahfouz, E., 2007, Textual evidence, In K.A. Bard, and R. Fattovich (eds.), Harbour of the pharaohs to the Land of Punt. Archaeological investigations at Mersa/Wadi Gawasis, Egypt, 2001-2005, 217-238. Naples. Pulak, C., 1998, The Uluburun [1] shipwreck: an overview, International Journal of Nautical Archaeology, 27(3), 188-224.

Pulak, C., 1999, The Late Bronze Age Shipwreck at Uluburun: Aspects of Hull Construction. In W. Phelps, Y. Lolos, Y. Vichos (eds.), The Point Iria Wreck: Interconnections in the Mediterranean ca. 1200 BC, 209-238. Athens.

Pulak, C., 2003, Mortise-and-Tenon Joints of Bronze Age Seagoing Ships, In C. Beltrame (ed.), Boats, Ships and Shipyards, Proceedings of the Ninth International Symposium on Boat and Ship Archaeology, 28-34.

Oxford.

Wachsmann, S., 1998, Seagoing ships \& seamanship in the Bronze Age Levant, College Station Texas. Ward, C. and Zazzaro, C., 2010, Evidence for Pharaonic seagoing ships at Mersa/Wadi Gawasis, Egypt. International Journal of Nautical Archaeology, 39(1), 27-43.

Ward, C., 2000, Sacred and secular: ancient Egyptian ships and boats, The University Museum, The University of Philadelphia for the Archaeological Institute of America, Philadelphia.

Ward, C., 2007, Ship timbers: description and preliminary analysis, In K.A. Bard, and R. Fattovich (eds.), Harbour of the pharaohs to the Land of Punt. Archaeological investigations at Mersa/Wadi Gawasis, Egypt, 2001-2005, 135-150. Naples.

Ward, C., 2009, Evidence for Ancient Egyptian Seafaring, in R. Bockius, (ed.), Between the Seas: Transfer and Exchange in Nautical Technology.Proceedings of the Eleventh International Symposium on Boat and Ship Archaeology, Mainz, 9-16. Mainz.

Ward, C., Zazzaro, C. and Abd el-Maguid, M., 2010, Super-sized Egyptian ships. International Journal of Nautical Archaeology 39(2), 387-89.

Zazzaro, C. and Calcagno, C., 2012, Ship components from Mersa Gawasis: recent finds and their archaeological context, In P. Tallet, and E. Mahfouz (eds.), 2009, The Red Sea in Pharaonic Times. In Proceedings of the Colloquium, 65-85. Cairo/Ayn Soukhna.

Zazzaro, C., 2007, Ship timbers and parts, cargo boxes, In K.A. Bard, and R. Fattovich (eds.), Harbour of the pharaohs to the Land of Punt. Archaeological investigations at Mersa/Wadi Gawasis, Egypt, 2001-2005, 185-87. Naples. 


\section{Figures:}

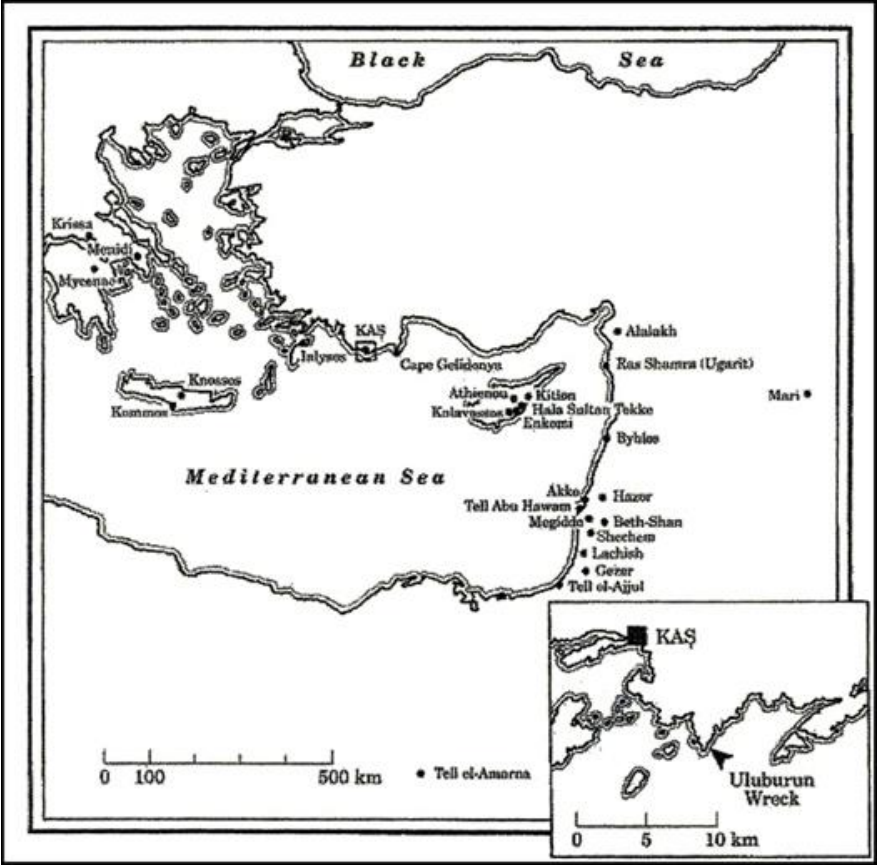

Figure 1. Map showing the location of the Uluburun shipwreck site (Courtesy of Pulak). (Pulak, 1998:189).

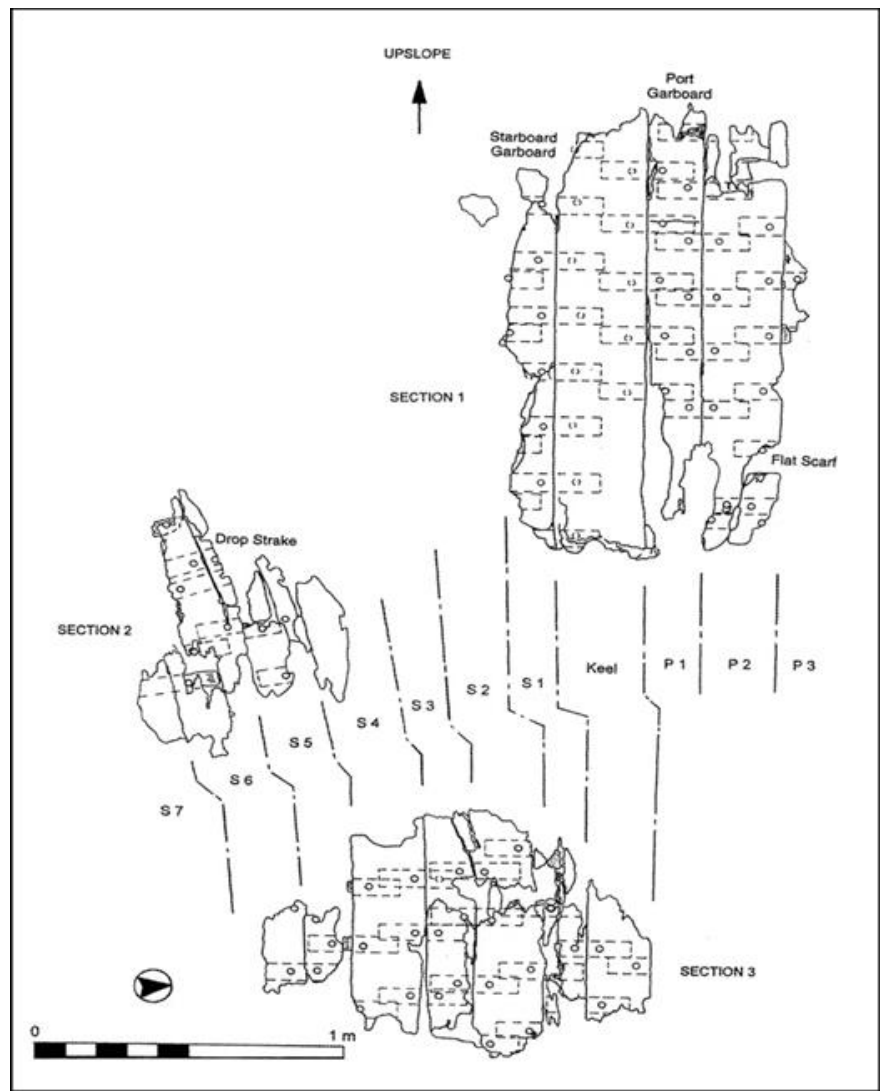

Figure 2. Plan of Uluburun ship wreck showing pegs securing each tenon in mortise (Drawing by Cemal Pulak. Courtesy of Pulak). (Pulak,1999:234). 


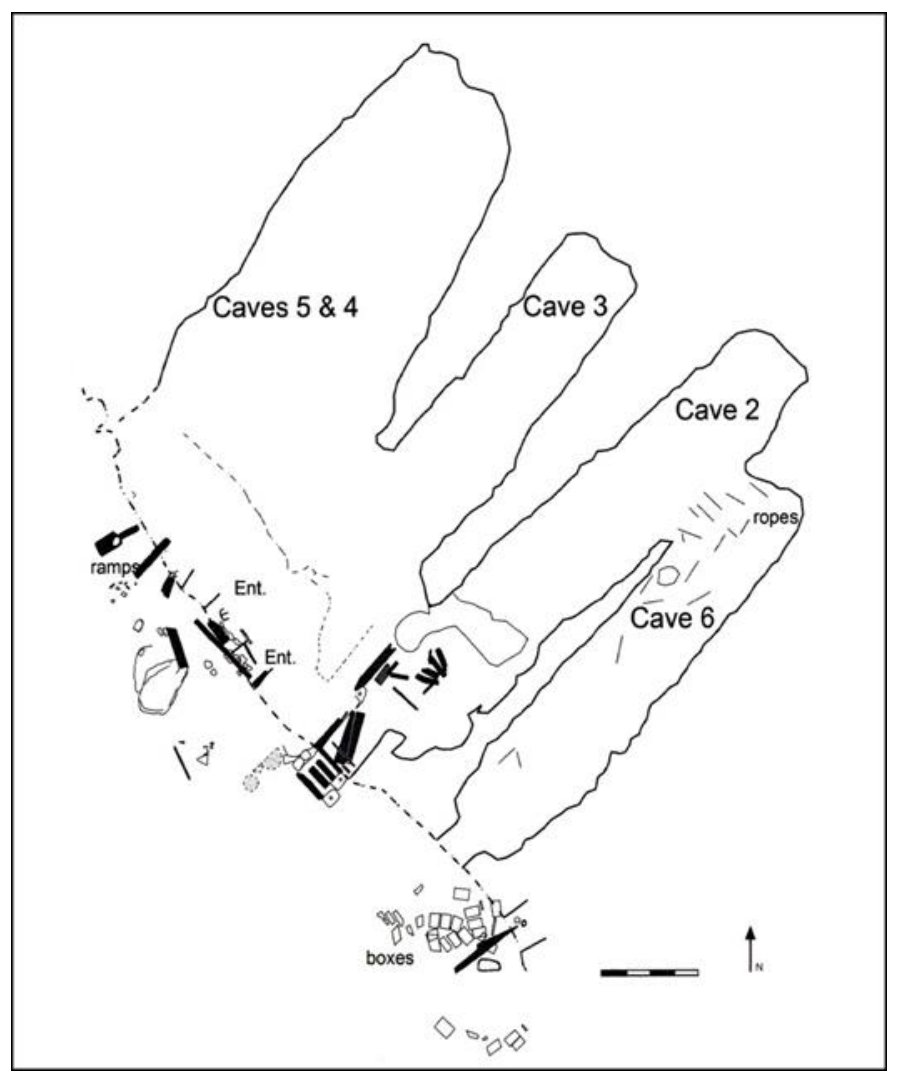

Figure 3. Plan showing caves distribution in Wadi Gawasis harbour. (Courtesy of the Joint Expedition at Mersa/Wadi Gawasis of the University of Naples "L'Orientale", Boston University, and ISMEO). (Ward and Zazzaro, 2010:28).

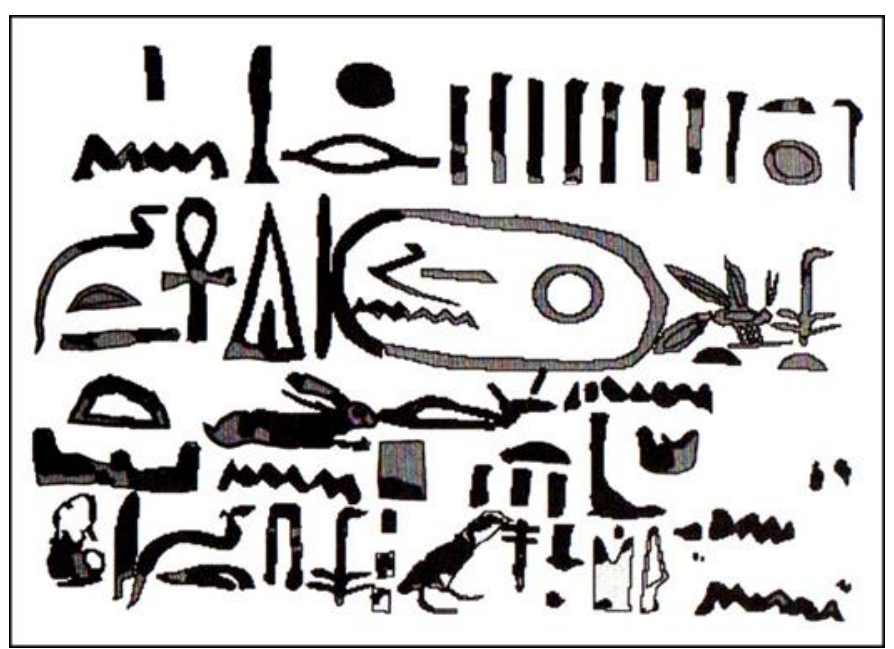

Figure 4. Amenemhet IV's inscription found on the wooden box (Drawing by Elsayed Mahfouz. Courtesy of the Joint Expedition at Mersa/Wadi Gawasis of the University of Naples "L'Orientale", Boston University, and ISMEO). (Bard and Fattovich, 2007:364) 


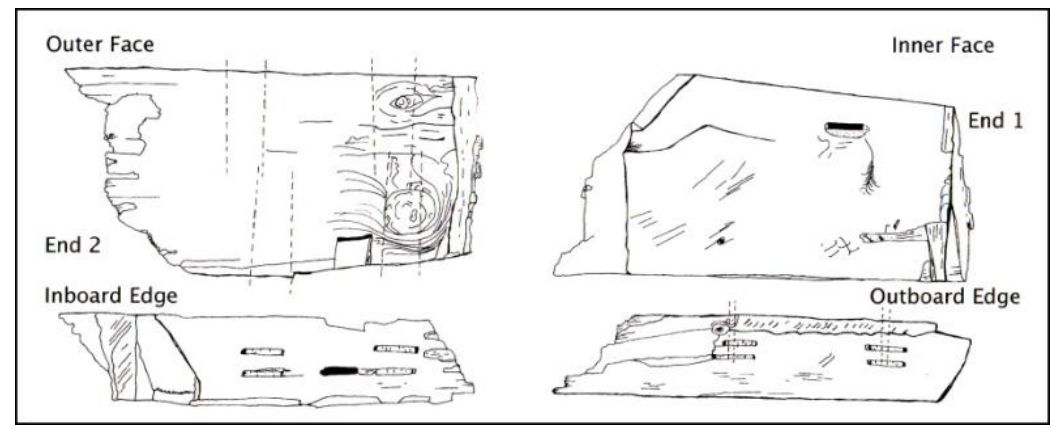

Figure 5. Drawing of massive segment T64 indicating pegs securing tenons in mortises found in Wadi Gawasis (Drawing by Cheryl Ward. Drawing used with permission of Cheryl Ward and courtesy of the Joint Expedition at Mersa/Wadi Gawasis of the University of Naples "L'Orientale", Boston University, and ISMEO). (Ward et al., 2010:388).

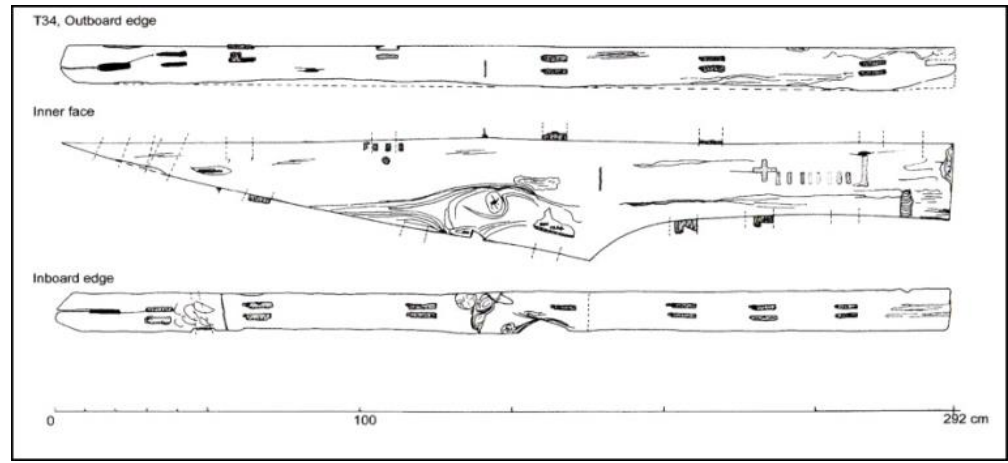

Figure 6. T34 hull plank which contains three pegs securing tenons found in Wadi Gawasis. (Drawing by

Cheryl Ward. Drwaing used with permission of Cheryl Ward and courtesy of the Joint Expedition at Mersa/Wadi Gawasis of the University of Naples "L'Orientale", Boston University, and ISMEO). (Ward and Zazzaro, 2010:32).

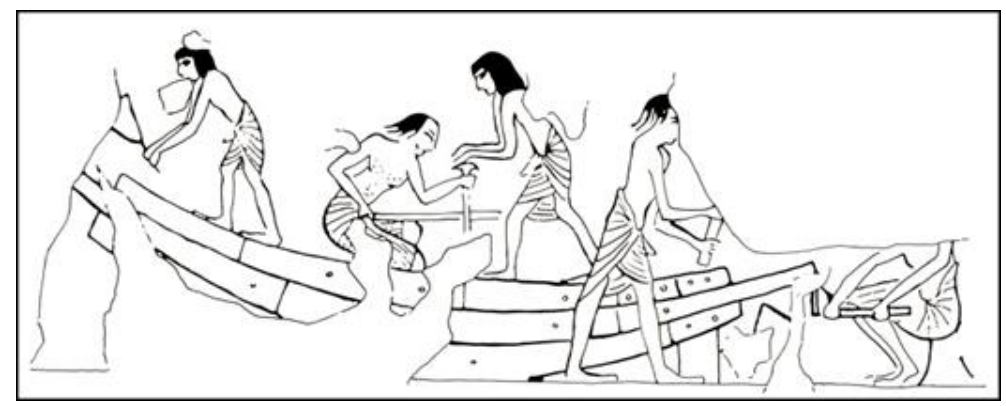

Figure 7. The ship construction scene of Qaha tomb painting at Deir El-Madinah showing 13 pegs. After Bruyere,1933@IFAO (Wachsmann, 1998:236). 


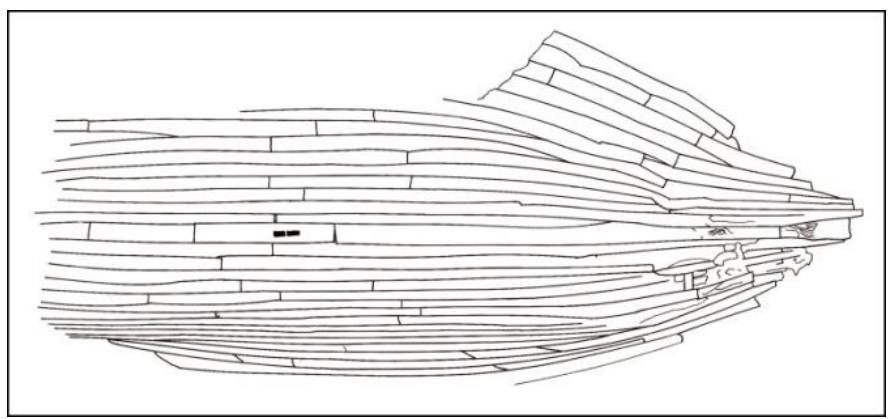

Figure 8. Sketch plan of the Mataria boat in full length. (Drawing used with permission of Cheryl Ward) (Ward, 2000:130).

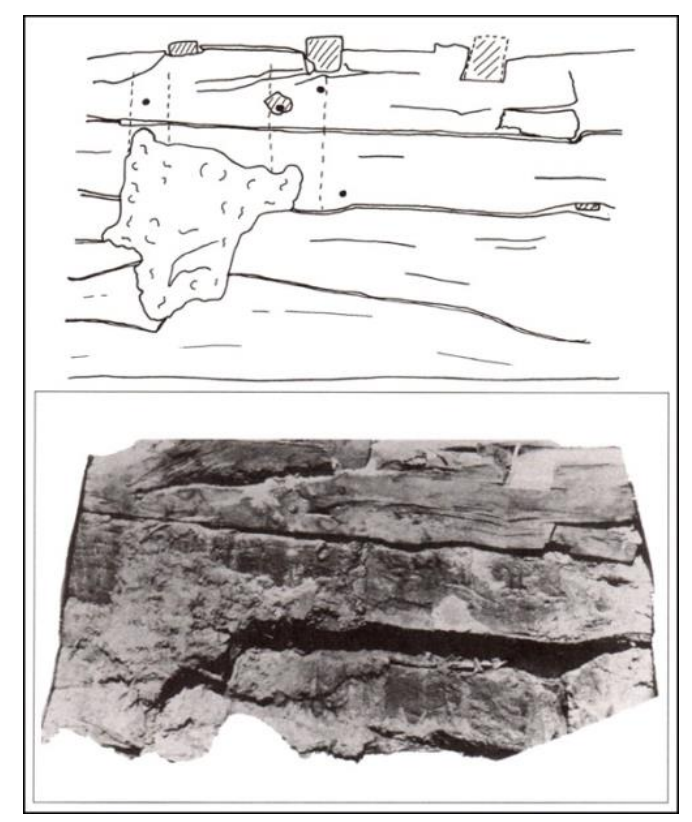

Figure 9. Part of inner surface of the Mataria boat and its hatch showing peg distribution in some tenons.

(Drawing and photo used with permission of Cheryl Ward) (Ward, 2000:132).

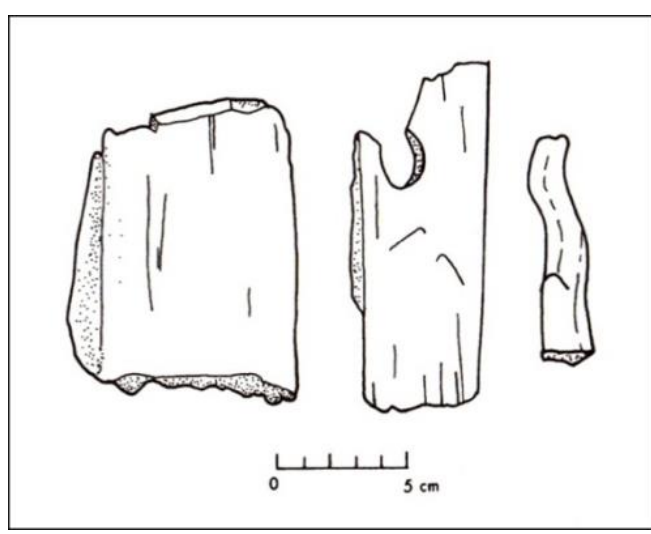

Figure 10. Half tenon, tenon with peg hole, and peg. (Drawing used with permission of Cheryl Ward) (Ward, 2000:133). 